\title{
APPLICATION OF MOLECULAR ABSORPTION AND EMISSION SPECTROMETRY FOR DETERMINATION OF FALSIFICATION OF PASTERISED MILK
}

\author{
V. Ischenko, O. Kochubei-Lytvynenko, N. Kvitkovskaya \\ National University of Food Technologies
}

A. Yakiminskaya, M. Ischenko

Taras Shevchenko National University of Kyiv

\begin{tabular}{l} 
Key words: \\
Milk \\
Fluorescence \\
Molecular absorption \\
spectroscopy \\
\hline \multicolumn{1}{c}{ Article history: } \\
Received 12.09.2018 \\
Received in revised form \\
03.09.2018 \\
Accepted 18.10.2018 \\
\hline
\end{tabular}

Corresponding author:

$\mathrm{V}$. Ischenko

E-mail:

ischenko_vn@ukr.net

\begin{abstract}
The article analyzes the problem of falsification of food products and, in particular, milk. An overview of the main types of falsification of milk and the causes that lead to it are reviewed. It is noted that now falsification of milk with its reconstituted analog, obtained from dry mixtures, is becoming widespread. An overview of recent scientific publications has shown that the method of molecular absorption and emission spectrometry (molecular fluorescence) along with NIR-spectroscopy is becoming popular as a screening method for fast identification of falsification of dairy products. The authors note that technique of molecular fluorescence spectroscopy makes it possible to detect conformational changes in proteins occurring under different conditions of production and storage of dairy products and indirectly determine the degree of heat treatment. Also analysis by molecular fluorescence technique does not require complex sample preparation and is characterized by high sensitivity.

The fluorescence spectra of milk samples exposed to different pasterization types by laboratory methods, also commercial milk samples and some dairy product samples obtained from dry milk and whey were studied. The fluorescence spectra of the samples were recorded at different wavelengths characteristic for tryptophan, products of Maillard reaction, nicotinamideadeninedinucleotide and riboflavin. The spectra show the fluorescence dependends on the degree of protein denaturation, that correlates with pasteurization type used for milk treatment. The best results were obtained from analyzing the fluorescence spectra of tryptophan and Maillard reaction products, as well as absorption spectra in the range of $200-250 \mathrm{~nm}$. The use of first and second derivatives of absorption spectra of these fluorophores makes it possible to identify additional weakly visible maxima, those can be used to detect a product made from dried milk.
\end{abstract}

DOI: $10.24263 / 2225-2924-2018-24-5-29$ 


\title{
ЗАСТОСУВАННЯ МОЛЕКУЛЯРНОЇ АБСОРБЦІЙНОЇ ТА ЕМІСІЙНОЇ СПЕКТРОМЕТРІЇ ДЛЯ ВИЯВЛЕННЯ ФАЛЬСИФІКАЦІЇ ПАСТЕРИЗОВАНОГО МОЛОКА
}

\author{
В.М. Іщенко, О.В. Кочубей-Литвиненко, Н.П. Квітковська \\ Національний університет харчових технологій
}

А.Г. Якімінська, М.В. Іщенко

Київський національний університет імені Тараса Шевченка

У статті проаналізована проблема фальсифікаиії харчових продуктів, зокрема молока. Проведено огляд основних видів фальсифікаиї молока та причин, які призводять до неї. Зазначено, щьо нині набуває поширення підміна молока його відновленим аналогом, тобто «молоком», одержаним із сухих сумішей. Огляд останніх наукових публікацій показав, щзо наразі все більшої популярності для виявлення фальсифікаиії молочної продукиії набуває метод молекулярної абсорбиійної та емісійної спектрометрії (флуоресиениія) як скринінговий метод. Автори відмічають, щэо саме метод флуоресцениії надає можливість детектувати конформачійні зміни білків, що відбуваються 6 різних умовах виробництва $і$ зберігання молочної продукиї, опосередковано визначати ступінь термообробки, не потребуе складної пробопідготовки $i$ характеризується високою чутливістю.

3 метою виявлення фальсифікаиії молока його відновленим аналогом досліджені спектри флуоресиенції лабораторно-пастеризованих, комериійних зразків молока різної пастеризаиії та молочного продукту, одержаного із сухого молока та молочної сироватки при різних довжинах хвиль, характерних для триптофану, продуктів реакиії Майяра, никотинамідаденіндинуклеотиду та рибофлавіну. Зі спектрів помічена залежність флуоресиениіі від ступеня денатураиії білків, що корелюе з видом пастеризації молока. Найкраще класифікаиія зразків спостерігається в спектрах флуоресиениії триптофану та продуктів реакиії Майяра, а також у спектрах поглинання в діапазоні 200-250 нм. Перша та друга похідна спектрів поглинання цих флуорофорів дає змогу виокремити додаткові мало видимі максимуми, що може бути використано для виявлення продукту, виготовленого із сухого молока.

Ключові слова: молоко, флуоресиенція, молекулярно-абсорбиійна спектроскопія.

Постановка проблеми. Сучасні економічні і політичні умови євроінтеграції України вимагають суттєвих змін у системи контролю та ідентифікації харчової продукції, оскільки головна вимога сучасного європейського підходу - забезпечення безпеки харчових продуктів з метою захисту життя i здоров'я громадян, а також запобігання діям, що вводять в оману споживачів. Тому виявлення можливої фальсифікації молока і молочних продуктів $\epsilon$ важливим питанням для виробників, товарознавців, науковців та споживачів, які мають бути впевнені, що продукти, які вони придбали, безпечні. Причин 
появи фальсифікації молока дві: одна пов'язана із сировиною (дефіцит молока в осінньо-зимовий період), друга - економічна: через низьку купівельну спроможність населення краще продається дешевий продукт.

Найчастіше фальсифікація молока здійснюється додаванням консервантів, розведення молока водою $з$ подальшим додаванням речовин з високим вмістом нітрогену для компенсації рівня вмісту білка, заміна молочного жиру жиром рослинного походження, підміна одного виду молока іншим, наприклад, більш дорогого козиного молока на коров'яче, підміна незбираного молока нормалізованим або навіть знежиреним, додаванням в деякі молочні продукти сироватки тощо [1]. Наразі серед українських виробників молочної продукції набуває поширення підміна молока його відновленим аналогом, тобто «молоком», одержаним із сухих сумішей, які, у свою чергу, можуть бути сфальсифіковані додаванням сироватки.

У лабораторіях контролю якості молочної продукції використовують так звані цільові аналітичні методи контролю. Проте ці методи в більшості випадків дають змогу визначати склад молока, але не всі види його можливої фальсифікації. Тому світова аналітична практика оцінки якості харчової продукції зосереджена на тому, щоб доповнити цільові аналітичні методи контролю нецільовими методами [2].

Аналіз останніх досліджень і публікацій. Нині все більшої популярності для виявлення фальсифікації молочної продукції набуває метод молекулярної абсорбційної та емісійної спектрометрії як скринінговий метод. Застосування молекулярної абсорбційної спектрометрії для визначення ступеня термічної обробки молока та фальсифікації ультрапастеризованого молока сироваткою описано в [3; 4]. Емісійна молекулярна спектрометрія (флуоресцентна спектроскопія) більш чутлива, ніж абсорбційна спектрометрія. Спектри флуоресценції більш селективні, ніж спектри інших спектроскопічних методів, в тому числі і спектри поглинання, оскільки флуоресцентні сполуки дуже чутливі до оточення (матриці). Також емісійна спектрометрія має переваги при перевірці якості продукції в режимі on-line, оскільки можна експресно і без руйнування виміряти сполуки, які утворюють при певних технологічних умовах [5; 6].

Основні процеси, що відбуваються при одержанні сухого молочного порошку: денатурація білка, рання і подальша реакція Майяра (накопичені продукти цієї реакції), ізомеризація лактози, часткове руйнування деяких вітамінів та інактивація більшості ферментів, зменшення вмісту йонного Кальцію. Для визначення м'якої термічної обробки молока (пастеризація) найчастіше застосовують визначення флуоресценції $\beta$-лактоглобуліна. Специфічні маркери, такі як лактулоза, фурозин та гідроксиметилфурфурол, застосовують для виявлення більш інтенсивної термообробки. На основі цього розроблені деякі флуоресцентні методи оцінки інтенсивності термічної обробки молока, такі як FAST-індекс [7], що являє собою співвідношення флуоресценції в молочній фракції при $\mathrm{pH}$ 4,6 накопичених продуктів Майяра до розчинного триптофану, який $є$ показником руйнування білків. У [8] було встановлено, що власні флуорофори лужної фосфатази, тобто коферменти нікотинамідаденіндинуклеотид (NAD) і флавінаденіндинуклеотид (FAD), можуть бути використані для визначення ступеня термічної обробки молока. Проте, щоб 
однозначно встановити ступінь термічної обробки молока i, відповідно, можливу підміну або додавання до молока відновленого продукту, потрібно як мінімум чотири маркери. Таке дослідження здійснили в [9], де були визначені показники термічної обробки: фурозин, лактулоза, альфа-лактальбумін, бета-лактальбумін, відсоток денатурованого лактоальбуміну, FAST-індекс, флуоресценція триптофану, $\beta$-лактоглобулін та лактопероксидаза.

Більш детально розглянули й оцінили процеси та зміни в молоці за різних температур і часу нагріву в [10] за допомогою фронтальної флуоресцентної спектроскопії. Метод зручний тим, що перед початком реального вимірювання не потрібно проводити попередню підготовку зразків. Результати можна отримати за відносно короткий проміжок часу порівняно зі звичайними методами.

Отже, флуоресценція дає можливість детектувати конформаційні зміни білків, що відбуваються в різних умовах виробництва і зберігання молочної продукції, опосередковано визначати ступінь термообробки, не потребує складної пробопідготовки і характеризується високою чутливістю.

Мета статті: оцінка можливості використання методів молекулярної абсорбційної та емісійної спектроскопії для виявлення фальсифікації молока, зокрема виявлення молочного продукту, виготовленого із сухих сумішей. Як можливі маркери були вибрані такі флуорофори, як триптофан, продукти реакції Майяра, рибофлавін і нікотинамідаденіндинуклеотид (далі - НАДХ).

Викладення основних результатів дослідження. У дослідженні використовували ацетатний буферний розчин $3 \mathrm{pH}=4,5-4$, розчини триптофану 3 концентрацією 1,0 мг/л та рибофлавіну 3 концентрацією 2,0 мг/л, які були виготовлені із реактивів класифікації «ч.д.а.». Записи спектрів поглинання в УФ та видимому діапазоні здійснювали на спектрометрі UV2401 PC (Shimadzu Corp, Японія), спектрів флуоресценції - на флуоресцентному спектрометрі LS-55 (Perkin-Elmer, США). Вимірювання проводилось на рН-метрі рН150МИ (Білорусь).

Для встановлення основних спектральних змін, що спостерігаються при пастеризації, проводилась лабораторна пастеризація натурального незбираного молока за різних температур і часу нагріву за допомогою магнітної мішалки з нагрівом. Пастеризацію здійснювали при $75^{\circ} \mathrm{C}$ на водяній бані. Під час термічної обробки відбирали аліквоти молока через різні проміжки часу.

Підготовка зразків для запису спектрів здійснювалась таким чином: до аліквоти об'ємом 1,0 мл додавали 9,0 мл ацетатного буферного розчину 3 $\mathrm{pH}$ 4,5-4,6 для осадження казеїну. Після додавання буферу зразки витримували 30 хв для повного осадження казеїну і центрифугували. Для кращого очищення від залишкових домішок і плівки жиру, що заважали спектрофотометричному визначенню розсіюванням світла, застосовувалось фільтрування за допомогою целюлозних мембранних фільтрів 0,45 мкм. Для запису спектрів флуоресценції зразки ще додатково розбавлялись у 10 разів, спектри поглинання реєструвались без додаткового розбавлення.

Умови запису спектрів флуоресценції та збудження різних флуорофорів у молоці з включеним коректором і вимкненою поляризацією на флуорометрі Perkin-Elmer LS-55 наведені в табл. 1. Подальша обробка спектрів здійснювалась з урахуванням фонового випромінювання ацетатного буфера. 
Таблиця 1. Умови запису спектрів флуоресценції та збудження

\begin{tabular}{|c|c|c|c|c|}
\hline \multirow{2}{*}{ Флуорофор } & \multicolumn{2}{|c|}{ Довжина хвилі } & \multicolumn{2}{c|}{ Діапазон вимірювання } \\
\cline { 2 - 5 } & $\begin{array}{c}\text { збуджуючого } \\
\text { світла } \lambda_{\text {ех }}, \text { нм }\end{array}$ & $\begin{array}{c}\text { випромінюваного } \\
\text { світла } \lambda_{\text {em }}, \text { нм }\end{array}$ & $\begin{array}{c}\text { люмінесценції, } \\
\text { нм }\end{array}$ & $\begin{array}{c}\text { 3будження, } \\
\text { нм }\end{array}$ \\
\hline Триптофан & 290 & 340 & $310-420$ & $520-320$ \\
\hline $\begin{array}{c}\text { Продукти реакції } \\
\text { Майяра }\end{array}$ & 330 & 420 & $350-500$ & $290-400$ \\
\hline НАДХ & 360 & 520 & $380-600$ & $290-500$ \\
\hline Рибофлавін & 450 & 550 & $470-600$ & $250-520$ \\
\hline
\end{tabular}

Примітка: швидкість сканування: 600 нм/хв., щілина вхідного монохроматора, $d_{1}$ : 10,0 нм, щілина вихідного монохроматора, $d_{2}: 7,5$ нм.

Спектри поглинання зразків молока реєструвались при спектральній щілині 1 нм 3 кроком сканування 1 нм в діапазоні 200-500 нм. Як розчин порівняння використовували ацетатний буфер.

Літературні дані про основні спектральні характеристики флуорофорів, зокрема ділянки збудження та випромінення флуоресценції, квантовий вихід $(Q, \%)$, наведено в табл. 2. Виходячи із значень квантових виходів речовин, очевидним є той факт, що рибофлавін має найкращі люмінесцентні властивості, проте в молоці він знаходиться в надзвичайно низьких кількостях, тож 3 флуорофорів найбільший інтерес представляє триптофан, який входить до складу білків сироватки, зокрема $\beta$-лактоглобуліну.

Нормовані спектри поглинання (abs), збудження (ех) та флуоресценції (em) вибраних флуорофорів представлені на рис. $1-2$.

Таблиця 2. Основні спектральні характеристики флуорофорів молока $[11 ; 12]$

\begin{tabular}{|c|c|c|c|}
\hline & $\lambda_{\max }^{\mathrm{ex}}, \mathrm{Hм}$ & $\lambda_{\max }^{\mathrm{em}}, \mathrm{Hм}$ & $Q, \%$ \\
\hline Триптофан & 276 & 355 & 12 \\
\hline Продукти реакції Майяра & 330 & 420 & низький \\
\hline NADH & 338 & 465 & 1,9 \\
\hline Рибофлавін & $444,372,268$ & 528 & 30 \\
\hline
\end{tabular}

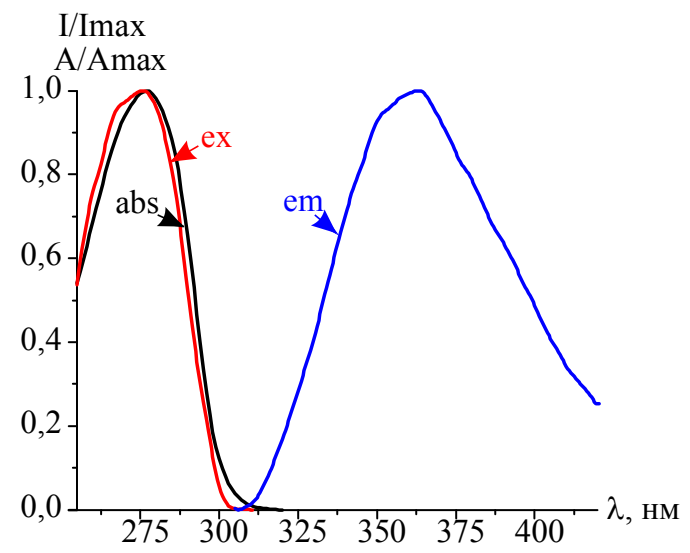

Рис. 1. Нормовані спектри поглинання, збудження та флуоресценції стандартного розчину триптофану ( $\mathrm{pH} 4,50 \pm 0,05)$ 


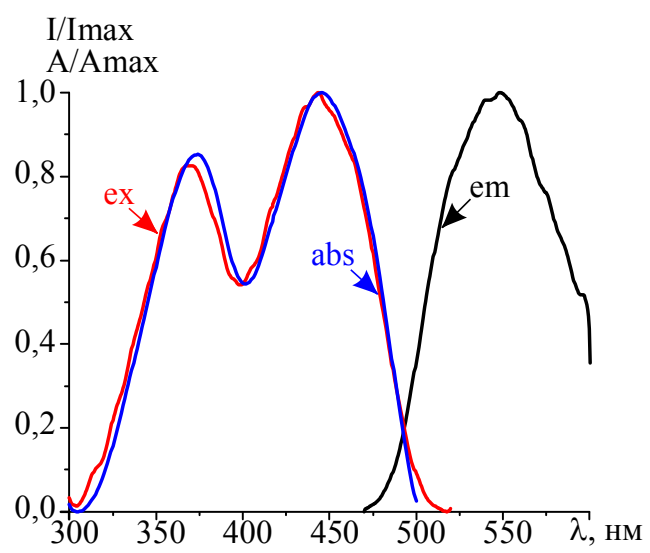

Рис. 2. Нормовані спектри поглинання, збудження та флуоресценції стандартного розчину рибофлавіну ( $\mathrm{pH} 4,50 \pm 0,5)$

Для перевірки можливості застосування молекулярної абсорбційної спектроскопії та флуоресценції вищеназваних флуорофорів як маркерів на молоко, яке виготовлене із сухого продукту, нами було проаналізовано партію зразків, що включала 3 зразки натурального незбираного молока, яке не проходило термообробку, 8 комерційних зразків пастеризованого молока, серед яких був один зразок ультрапастеризованого, 8 зразків виготовлених із сухого молока (так зване відновлене молоко) та 2 зразки відновленої молочної сироватки. Зразки сухого та пастеризованого молока були придбані в місцевих супермаркетах, зразки натурального молока були отримані від надійних постачальників. Для приготування відновленого молока дотримувалися рецепту на упаковці: сухе незбиране (12,5 г на 100 г розчину), сухе знежирене (9 г на 100 г розчину). Аналогічно була приготована відновлена сироватка (6 г на 100 г розчину). При цьому зразки готувалися на звичайній дистильованій воді та на пом'якшеній, після чого відновлене молоко було повторно пастеризоване в лабораторних умовах до $80^{\circ} \mathrm{C}$.

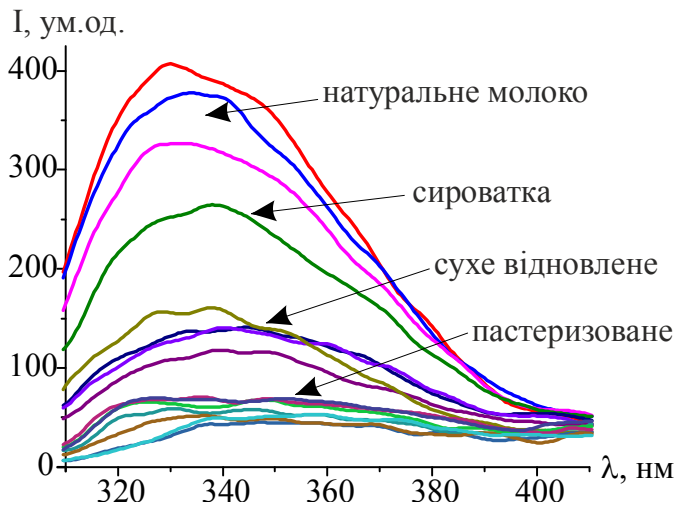

Рис. 3. Спектри флуоресценції триптофану при $\lambda_{\text {ex }}=290$ нм комерційних зразків молока 


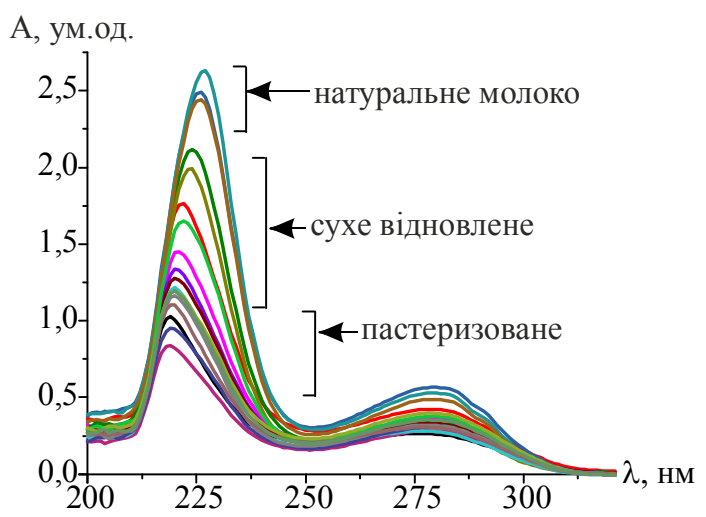

Рис. 4. Спектри поглинання комерційних зразків молока

Було зареєстровано спектри флуоресценції комерційних зразків молока різної пастеризації при різних довжинах хвиль відповідним досліджуваним флуорофорам. Усі спектри флуоресценції молочних продуктів були згладжені за методом Adjacent-Averaging для кращої інформативності аналітичного сигналу та усунення шуму. Встановлено, що найбільш помітні зміни відбуваються у спектрах флуоресценції триптофану. Для інших флуорофорів помітної різниці у спектрах флуоресценції залежно від ступеня пастеризації й термічної обробки не спостерігається. На рис. 3 наведено спектри флуоресценції досліджених зразків молока. Спектри поглинання аналізованих проб молока наведені на рис. 4.

Зі спектрів флуоресценції триптофану була помічена залежність флуоресценції від ступеня денатурації білків у сироватці, що корелює з видом пастеризації молока.

За спектрами можна відносно класифікувати молоко за типом термообробки. Натуральне молоко найбільше поглинає в діапазоні 200-350 нм. Перша та друга похідна спектрів поглинання (рис. 5) молока дає змогу виокремити додаткові маловидимі максимуми, що може бути використано для кращої ідентифікації молочних зразків, i, відповідно, для виявлення асортиментної фальсифікації.

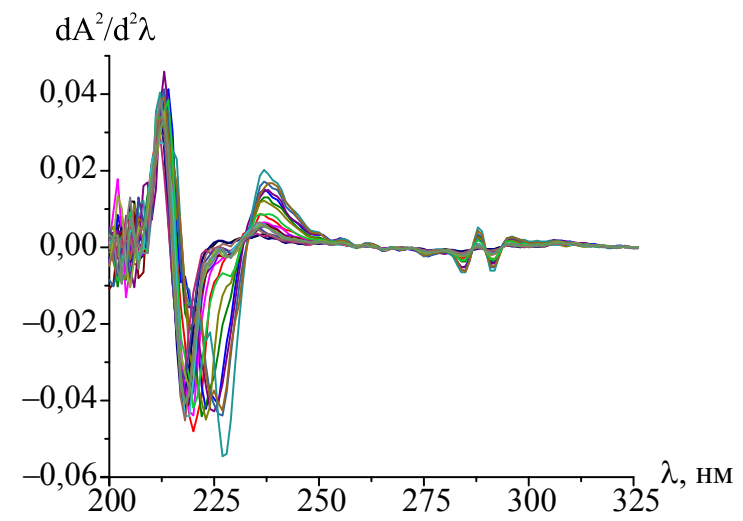

Рис. 5. Друга похідна спектрів поглинання комерційних зразків молока 


\section{Висновки}

Найкраще класифікація зразків молока спостерігається в спектрах флуоресценції триптофану та продуктів реакції Майяра, а також у спектрах поглинання в діапазоні 200-250 нм. Перша та друга похідна спектрів поглинання цих флуорофорів дає змогу виокремити додаткові маловидимі максимуми, що може бути використано для виявлення продукту, виготовленого із сухого молока.

\section{Література}

1. Коваленко Д.Н. Фальсификация молока и молочных продуктов. Переработка молока. 2011. № 3. С. 8-11.

2. Detection of adulteration in milk: A review / Amrita Poonia, Alok Jha, Rjan Sharma, Harikesh Bahadur Singh, Ashwini Kumar Ra, Nitya Sharma. International Journal of Dairy Technology. 2016. V. 69. P. 1-20.

3. Lactulose determination in UHT milk by CZE-UV with indirect detection / Leandra Natáliade Oliveira Neves, Rafael Marques, Paulo Henrique Fonsecada Silva, Marcone Augusto Lealde Oliveira. Food Chemistry. 2018. V. 258. P. 337-342.

4. Determination of whey protein to total protein ratio in UHT milk using fourth derivative spectroscopy / Beatriz Miralles, Begona Bartolome H, Mercedes Ramos et. al. International Dairy Journal. 2000. V.10. P.191-197.

5. The FAST method, a rapid approach of the nutritional quality of heat-treated foods/ I. Birlouez-Aragon, J. Leclere, C. Quedraogo, et. al. Mol.Nutr.Food Res. 2001. V. 45. P. 201-205.

6. Schamberger G., Labuza T.Evaluation of front-face fluorescence for assessing thermal processing of milk. J. Food Sci. 2006. V. 71. P. 69-74.

7. Birlouez-Aragon I., Sabat P., Gouti N.A new method for discriminatingmilk heat treatment. International Dairy Journal. 2002. V. 12. P. 59-67.

8. Kulmyrzaev A., Levieux D., Dufour E. Front-face fluorescence spectroscopy allows the characterization of mild heat treatments applied to milk. Relations with the denaturation of milk proteins. J. Agric. Food Chem. 2005. V. 53. P. 502-507.

9. Evaluation of tracers for the authentication of thermal treatments of milks / M. Feinberga, D. Dupont, T. Efstathiou, et. al. Food Chemistry. 2006. V. 98. P. 188-194.

10. Kulmyrzaev A., Levieux D., Dufour E. Front-Face Fluorescence Spectroscopy Allows the Characterization of Mild Heat Treatments Applied to Milk. Relations with the Denaturation of Milk Proteins. J. Agric. Food Chem. 2005. V. 53. P. 502-507.

11.Database of Fluorescent Dyes, Properties and Applications, Fluorophores. URL: http://www.fluorophores.tugraz.at/substance/ Fluorescent Substances (Перевірено 03.05.2018).

12. Food Fluorescence Library. URL: http://models.life.ku.dk/foodfluor. FOODFLUOR. 